\title{
MOTIVATING SECOND LANGUAGE LEARNERS: FROM MAJOR L2 MOTIVATION THEORIES TO IMPLICATIONS FOR L2 CLASSROOM PRACTICE AND RESEARCH
}

\author{
Truong Thi My* \\ Hanoi University \\ Km9, Nguyen Trai Road, Nam Tu Liem district, Hanoi, Vietnam \\ Received 28 September 2020 \\ Revised 24 December 2020; Accepted 20 January 2021
}

\begin{abstract}
Motivation has long been emphasized as a determinant factor in a learning process in general, and second language (L2) acquisition in particular. Equivalent to such importance, a vast number of theories and models have been proposed in the literature to explain why students choose to learn a second language. The proliferation of L2 motivational theories and models in the literature, however, might have caused certain confusion to practitioners and researchers in choosing a suitable methodological and theoretical framework for their teaching practice and research. This paper aims to address this concern by critically reviewing the major L2 motivation approaches and their featured L2 motivational models to date, based on which several implications will be made for L2 teachers who seek to create a motivating language teaching practice, and for L2 researchers whose goal is to gain a comprehensive understanding of the construct in their empirical enquiries.

Keywords: second language (L2) motivation, literature review, second language teaching, L2 motivation theories
\end{abstract}

\section{Introduction}

For a long time, the vital role of an individual's motivation in his/her learning has been emphasized by many educational psychologists (e.g. Cave \& Mulloy, 2010; Dörnyei, 2007; Graham \& Weiner, 2012; Cook \& Artino, 2016). As stressed by Cave and Mulloy (2010), information about how and why people learn is essential in helping educators to design effective instructional practice. In the field of second language (L2) education, motivation is frequently mentioned as a factor worthy of special attention. Both practitioners and researchers consistently share the view that learners' motivation affects the success of their L2 learning (Dörnyei, 2001b, 2005, 2007; Hadfield \& Dörnyei, 2013). According to Dörnyei (2007), it is not so much the quantity and the quality of L2 input, the teaching methods applied, or the nature of the L2 learning tasks, but the continuing motivation in learners that can "inspire a lifelong commitment to the subject matter" (pp. 719-720).

\footnotetext{
Tel.: (+84)377682510

Email: truongthimy@hanu.edu.vn
}

Being of such importance, L2 motivation has been illuminated on via numerous theories and approaches over the past five decades. Serving a shared purpose of helping teachers to create motivating teaching practices, and researchers to better understand the L2 motivation construct, the proliferation of $\mathrm{L} 2$ motivation theories, however, must have caused certain difficulty for teachers and researchers in selecting a theoretical framework that best suits their context and research purposes (McEown, Noels, \& Chaffee, 2014). This suggests a need for a comparative review of the most influential models in the vast L2 motivation literature with concrete implications for practice and research.

This paper aims to address this need by critically reviewing the major approaches to understanding L2 motivation to date, as well as their corresponding featured motivational models. Based on the discussion of the strengths and flaws in each L2 approach and model chosen to review, and of them all collectively, several practical and methodological recommendations for both L2 teachers and researchers will be presented.

The review starts with a brief definition of motivation before examining how the understanding of the construct has evolved over 
time through the analysis of four major approaches in the history of L2 motivation research. The paper then discusses the literature collectively to draw implications for practice and research at the end.

\section{Motivation in mainstream psychology}

Before L2 motivation literature is critically reviewed, this section provides readers with a general understanding of the construct by defining "motivation", its characteristics and categories in mainstream psychology.

By definition, human motivation simply refers to the reasons why people think and behave in the way they do or the process whereby a goal-directed activity is initiated and sustained (Kazdin, 2000). In another mainstream psychology text, Graham and Weiner (2012) defined motivation as "what gets people's behaviour started, what directs, energizes, sustains, and eventually terminates the action" (p. 367). It is clear from these definitions that insights into an individual's motivation for an action cannot only explain why s/he does so, but also indicate how long s/he is willing to sustain the activity and how much effort $\mathrm{s} / \mathrm{he}$ is going to spend pursuing it. This also implies two aspects of the motivational construct, namely, the choice aspect (why a person behaves the way s/he does), and the intensity aspect (how much s/he wants to do it).

In terms of characteristics, it is generally agreed that motivation is temporal, dynamic (Gardner, 1985; Gottfried, 1990; Dörnyei, 2001b; MacIntyre, 2002; Graham \& Weiner, 2012); and domain-specific (Fernet et al., 2008; Gottfried, 1990). This means motivation varies over time, across subject areas, learner groups and learning situations. Such characteristics necessitate the account of factors that influence motivational changes in the whole course of an action in a theory or model that aims to explain an individual's motivation for such an action.

Concerning categorization, most educational psychologists have framed motivation in the extrinsic/intrinsic dualism. For learning to be best conditioned psychologically, both intrinsic motivation (i.e. the internal drive to follow one's interest to enhance knowledge and skills and become more capable), and extrinsic motivation (the belief that the goal of learning is instrumentally beneficial and achievable) should be present (Day, 1999). However, educators normally consider intrinsic motivations to be more desirable and lead to better learning outcomes than extrinsic drives (Ryan \& Deci, 2000; Graham \& Weiner, 2012).

\section{Motivation in second language acquisition}

Having long been recognized as a significant predictor of L2 achievement, L2 motivation has been rigorously researched in the last five decades. This section critically reviews the most prevalent approaches to understanding L2 motivation, starting with the earliest social-psychological approach, and concluding with the latest socio-dynamic approach.

\subsection{The social-psychological approach}

The first foundation in the long history of L2 motivation research was laid with the socialpsychological approach which features the two-fold formulation of L2 motivation proposed by Gardner and Lambert (1972). They theorize that the L2 learning process has important psychological and social aspects that make the motivation to learn an L2 differ from the motivation to learn all other subjects. That is, language learners are expected to acquire not only the linguistic knowledge, but also to adopt the L2 native community's distinct linguistic styles and behaviors (Gardner \& Lambert, 1972). It is, according to Gardner and Lambert (1972), primarily the learners' attitudes towards the L2 native speakers and their culture that directly affect their learning motivation and performance. This led these two social psychologists to propose two kinds of motivation in L2 learning: the "integrative" motivation referring to "a willingness to become a member of another ethnolinguistic group" (Gardner \& Lambert, 1972, p. 12), and the "instrumental" type denoting "a desire to gain social recognition or economic advantages through knowledge of a foreign language" (ibid., p. 14). To be more specific, those who are integratively motivated choose to learn an L2 because they are genuinely interested in the language itself and its culture, or want to be identified with the target people. Those who are instrumentally motivated, on the other hand, 
aim at the practicality and utility of the L2 proficiency, for example, to have better job opportunities, or to gain course credits. Of the two motivational orientations, integrativeness is expected to be more desirable and lead to higher outcomes in L2 learning than the other (Gardner \& Lambert, 1972; Gardner, 1985).

On this theoretical basis, Gardner (1985) devised the Attitude/Motivation Test Battery (AMTB), an instrument to quantify the amount of motivation. This includes three sub-scales measuring three constructs that would collectively underlie a learner's motivation for learning an L2: (i) the motivation intensity (i.e. how much effort a person invested or is willing to invest in learning the language; (ii) the attitudes towards learning the L2 (i.e. how much enjoyment the person feels when s/he learns the language); and (iii) desire to learn (i.e. how much the learner personally wants to learn the L2) (Ortega, 2009). The latest version of the instrument (Gardner, 2004) consists of 104 Likert-scale statements measured on a 6-points continuum, ranging from strongly disagree (scored 1) to strongly agree (scored 6), and seven items on a 7-point rating of various types (e.g. weak-strong; very low-very high; unfavorable-favorable). Researchers who adopt the instrument may select the specific contents that suit best their research purposes.

Gardner's and his associate's socialpsychological perspective was noted as being radically ahead of its time (Dörnyei, 2005) since it had, for the first time, distinguished L2 motivation research from the mainstream motivational psychology, which was then still dominated by purely individual-cognitive perspectives on motivation. In light of this differentiation, L2 motivation is rigorously articulated in terms of both motivation per se (effort, desire to learn) and its socialpsychological contributors (attitudes, learning orientations). In fact, Gardner's and Lambert's (1972) theory and the subsequent model of AMTB, since its inception, has underpinned a wealth of empirical research that aims to measure motivation as an individual-difference variable in L2 acquisition and predicts its causal link with other aspects of L2 learning and with L2 achievement throughout two decades thereafter (Gardner \& Lambert, 1972; Gardner, 1985; Gardner \& MacIntyre, 1993; Masgoret \& Gardner, 2003; Ditual, 2012). Current research examining the cultural and attitudinal factors that contribute to students' motivation in English language learning is still found based its argument on Gardner's and associates' (1972, 2004) work (e.g. Lai \& Aksornjarung, 2019; Darmanto, 2020).

Although these empirical studies largely confirm the validity of the socio-psychological approach as well as the role of motivation as a causal variable in predicting L2 success, the model nevertheless has not gone unchallenged. First, some studies (Kruidenier \& Clement, 1986; Belmechri \& Hummel, 1998) did not detect the presence of integrative motivation in certain groups of second language learners, but instead revealed a different set of motivators: instrumental, friendship, travel, selfunderstanding, knowledge, whose dominant orientations vary across learning situations. Second, the definition of integrative motivation appears inapplicable to the L2 learners who demonstrate very little or no genuine interest in the target culture due to limited opportunities to interact with the native speakers. The presumably superior influence of "integrativeness" on L2 achievement is also challenged when instrumental motivation was actually found to be much more powerful among this group of learners in several cases (Lukmani, 1972; Gonzales, 2010). The reason is that when English is increasingly viewed as an international language, the notion of integrating with native speakers from specific Anglophone communities has become less and less meaningful (Coetzee-Van Rooy, 2006). Not only was the power of integrativeness found problematic, the correlation between learners' attitudes and their L2 motivation was also not as positive as expected by the model in certain contexts. In Lai and Aksornjarung's (2018) study on Thai EFL students for instance, the research sample did not show a level of motivation that duly matched their reported positive attitudes towards English language learning. Research findings as such led several notable scholars to critiquing Gardner's sociopsychological model as being too deterministic and static (Ellis, 2008; MacIntyre, 2002). On the one hand, it considers motivation as an individual-difference factor that obviously determines a learner's L2 success. It also seems to ignore, on the other hand, the dynamic character of motivation, which causes it to constantly change as a result of different learning experiences and a multiplicity of other 
purely personal factors. Acknowledging this limitation after decades of research, Gardner (2010, p. 59) conceded that the sociopsychological model could only account for "general relationships", and is unable to provide context-specific and individualized advice to L2 teachers on how to motivate their students.

\subsection{The cognitive-situated approach}

The limitations of the social-psychological approach as discussed above led to the emergence of what Dörnyei (2005) named the cognitive-situated approach in motivation research during the 1990s. The approach is influenced by two interrelated trends: (i) the desire to incorporate cognitive theories in general educational psychology in the analysis of L2 motivation and (ii) the need to shift from a macro socio-psychological perspective to a more situated view of L2 motivation in specific learning contexts, for example, classrooms. The resulting models of motivation under this approach are those considering motivation in a particular learning situation (e.g. classroom environment, course material, instructional methods) through the lens of one cognitive notion in mainstream psychology. Some of the most influential concepts considered include "self-determination" - which posits that higher motivation and subsequently increased learning outcome is engendered when learners are more involved in the decision-making process and self-determine their learning goals and styles (Deci \& Ryan, 1985; Crookes \& Schmidt, 1991); "self-efficacy" - the belief in one's ability to succeed in L2 learning; the stronger the belief, the more motivated the learner is supposed to be (Clement, Dörnyei, \& Noels, 1994); and "attributions" (Weiner, 1992), which asserts that the types of reasons to which learners attribute their L2 performance, being either effort-related or ability-related, will shape their motivation in the L2 learning process (Dörnyei, 2005). Examples of empirical studies applying and applauding the applicability of this approach in L2 motivation research are Otoshi and Heffernan (2011), Thurman (2013), and Rahmanpanah (2017). Quantitatively designed and focusing on English as a second language (ESL) learners, these studies confirmed the significant effects of learners' autonomy, self-efficacy (Rahmanpanah 2017; Thurman, 2013); teachers' support of students' needs for competence and relatedness (Otoshi \& Heffernan, 2011) on the L2 motivation of the researched participants.

This shift in L2 motivational research is said to acknowledge one major development in L2 motivation study: recognizing the temporal and dynamic nature of the motivational construct. In fact, much research under the approach has shown that learners' motivation can vary across different individual cognitions (e.g. self-confidence, explanation of progress or lack thereof) (Ellis, 2008). Moreover, the focus of the cognitive-situated approach on classroom processes has started to allow research framed under this approach to yield practical advice to language teachers (Boo et al., 2015).

This discovery is, however, still limited in its characterization of motivation as a conscious process that happens within a relatively short duration (Boo et al., 2015). It thus does not suffice to fully address the instability of motivation during an extended learning event, such as a lesson, or the whole course of learning (Ushioda \& Dörnyei, 2012). To address this, the process-oriented approach was developed at the turn of this century.

\subsection{The process-oriented approach}

The process-oriented approach to understanding L2 motivation features the attempt to capture the temporal feature of the construct, which the previous theories fail to, at least explicitly, account for (Dörnyei, 2002). An outstanding outcome of such an attempt is Dörnyei and Ottos's (1998) process model which describes L2 learning motivation as experiencing three distinct stages: (1) "preactional" featuring choice motivation, (2) "actional" concerning executive motivation, and (3) "post-actional" involving learners' evaluation of the learning experiences.

The choice motivation in phase 1 contains three sub-elements that occur prior to a language learning event, namely goal setting, information intention, and enactment (Dörnyei $\&$ Ottos, 1998, p. 47). The subsequent actional phase starts at the onset of the action and goes on under the effects of three basic processes, including subtask generation and implementation, appraisal of environmental support and on-going progress, and action control mechanisms. Finally, the post-actional phase, which begins upon the achievement of 
goals or termination of the action, involves causal attributions about the result of the whole learning process, and inferences of future action orientations. The whole actional sequence is fueled by the so-called "motivational influences" (Dörnyei \& Ottos, 1998, p. 51), appearing in and corresponding to every stage of the motivation process. It is beyond the scope of this review to exhaustively list all these influences, but some examples include language attitudes that direct goal setting in the initial phase, learners' sense of autonomy that affects the actional stage, and teachers' feedback that may shape post-actional evaluation (Dörnyei \& Ottos, 1998).

Such a "flexible" model was found superior to its "static" antecedents in its ability to distinguish conceptually the motivations to engage in learning an L2 (reasons, decisions, goals) from motivations that sustain the engagement during the L2 learning process (feelings, behaviors, reactions to learning environment) (Ushioda \& Dörnyei, 2012). Projecting the wax and wane of motivation on the whole process of L2 learning, the model also provides systematic and helpful guides for teachers on how to create motivating teaching practice (Dörnyei, 2007). Last but not least, the model is able to incorporate into its scope other past motivational concepts, for example, integrative motivation and instrumental motivation in the pre-actional and actional stage, or attribution in the post-actional stage, thus offering a more extended framework for research than its predecessors (Ellis, 2008). Examples of studies that applied and applauded the validity and usefulness of the procedural view of L2 motivation include Dörnyei and Csizér (2005), Inbar et al. (2001), Ushioda (2001), Hiromori (2009), and Khudur (2019). Although conducted at different scales and adopting different research designs, all of these studies found motivational variations over time, whether it be a historical period (Dörnyei \& Csizér, 2005), a school year (Inbar et al., 2001), or a particular course (Ushioda, 2001; Hiromori, 2009; Khudur, 2019) thanks to the application of process-oriented L2 motivation framework.

The process model of L2 motivation, however, exhibits two shortcomings: (i) it assumes a clear definition of the starting and ending point of a learning process and (ii) it does not acknowledge the possible interference from other motivational processes which the learner may be simultaneously engaged in (Ushioda \& Dörnyei, 2012). In other words, it still treats motivation as an individual difference factor that is relatively stable and easily identifiable, which in fact has been proved to be highly sensitive to context specificity in reality (Al-Hoorie, 2017). These short-comings actually reveal the limitations of most studies in L2 motivation to date; that is, they have mostly attempted to draw an explanatory linear relationship between motivation and learning outcomes without adequately considering the full situated and dynamic complexity of the whole L2 learning process with various factors that may shape a learner's motivation (Ushioda \& Dörnyei, 2012).

\subsection{The socio-dynamic approach}

The latest movement in L2 motivation research has shifted to a more dynamic contextual perspective in analysing motivation, which is marked by the socio-dynamic approach. In light of this approach, motivation is no longer treated as an individual-difference variable, but rather, as an integral part of organic dynamic systems which evolve and develop in a non-linear manner and in the interaction of multiple personal, social and contextual factors (Dörnyei, 2009; Ushioda, 2009; Dörnyei, MacIntyre \& Henry, 2015). The approach is thus characterized by a need to theorize L2 motivation "in ways that take account of broader complexities of language learning and language use in the modern globalized world - that is, by reframing L2 motivation in the context of contemporary theories of self and identity" (Dörnyei \& Ushioda, 2012, p. 398).

Dörnyei's (2009) conceptualization of the "L2 Motivational Self System" (LMSS), based on two parent theories of "possible selves" (Markus \& Nurius, 1986) and self-discrepancy (Higgin, 1987) in psychology, is one noteworthy response to this need. Central in the model is the concept of "ideal self", representing all the attributes that a person ideally wishes to possess (as revealed in his/her personal hopes, wishes, desires), and the complementary concept of "ought-to self", signifying the attributes that a person feels necessary to possess as a result of his sense of responsibilities, obligations and duties. A principle is that one's psychological desire to 
bridge the gap between the "current actual self" and "future self" will serve as a great source of motivation for one to learn. Investigations into the selves must also take into account their interaction with the third component of the LMSS - L2 learning experience, which contains the specific motives shaped by the immediate learning environment. (Dörnyei, 2005, p. 106). According to Ushioda (2009), these motives can be instructor-specific (e.g. teachers' professional profile and nature of feedback), course-specific (e.g. the teaching materials, the mode of delivery), or learner group-specific (e.g. the dynamics of the group of learners learning together).

Dörnyei's (2009) LMSS under the sociodynamic approach has a number of advantages. First, by considering the individual self system with its full complexity and relationship with other social and contextual facets (learning experiences, sense of obligation, responsibilities), the model offers a comprehensive and versatile framework for L2 motivation research under the socio-dynamic approach. Ortega (2009) noted that the conceptualization as such has opened "the horizon to research on individual differences where cognitive, conative and affective dimensions can be blended and studied interrelated" (p. 188), and Boo et al. (2015) acknowledged the model's ability to afford both quantitative and qualitative methodologies. This can actually be seen in the surge of studies conceptually framed under the LMSS and of various designs since 2011 (Boo et al., 2015) in both ESL (e.g. King, Yeung \& Cai, 2019; Papi et al., 2018), and learning languages other than English (LOTEs) contexts (e.g. BerardiWiltshire, Bortolotto \& Morris, 2020). Second, the notion of "ideal language self" in the LMSS has reinterpreted Gardner's concept of "integrativeness" in an interesting way, being for example, a personal desire to be proficient in English as an international language (Ellis, 2008). This has addressed the conceptual issue of integrative motivation as discussed earlier, extending its application even to contexts where chances to interact with the target language community are not present. Third, the focus on how learners conceive themselves has laid an important foundation for research into practical strategies to initiate, sustain, and enhance learners' motivation throughout the learning process (Cheng \& Dörnyei, 2007; Hadfield \& Dörnyei, 2013).

Shortcomings, however, are still noticeable. Ushioda and Dörnyei (2012) point out that a challenging question remains about how to operationalize the complex and dynamic relationships between learner, language and environment in measurable terms. The advanced L2 Motivational Self System is also not far from problematic. As "humans $[\ldots]$ are inherently social beings" (Dörnyei \& Ushioda, 2009 , p. 353), one's perceptions about "selves" are supposed to be grounded in the social environment $\mathrm{s} / \mathrm{he}$ is in and the constant interactions $\mathrm{s} / \mathrm{he}$ has with that environment. Given such a social influence, it is thorny to decide with absolute confidence the desired self a learner perceives at a certain time is "ideal", i.e. the possible self "that is fully owned by the leaner" and "not imposed by others" (ibid., p. 353). Finally, the concept of strongly goal-oriented future self might not apply to learners of the languages that are not associated with strong instrumental utility (Duff, 2017). In fact, while well-defined L2 learning goals (an integral part of the learner's future self) are considered a strong motivational force in the LMSS, the total absence of such was interestingly found in highly motivated learners of te reo Māori, an indigenous New Zealand language (Berardi-Wiltshire, Bortolotto \& Morris, 2020). The complexities and nuances behind the motivation of LOTEs are therefore not yet fully accounted for under the sociodynamic L2 motivation approach.

\section{Discussion and implications}

It can be seen from the review above that the concept of L2 motivation and its full complexity has been gradually uncovered with the increasing sophistication of the analytical framework over time. From a static notion bearing a simplified linear relationship with learning outcomes, motivation has recently been depicted as a temporal and dynamic construct, which constantly changes under the effects of numerous variables in the learning process. Throughout the evolution process, later theories in consecutive stages did not simply replace but modified and complemented former ones, creating certain overlaps and subtle interactions (Boo et al., 2015). 
It is, however, striking to notice that none of the existing approaches and models would, by itself, be entirely adequate to serve as a comprehensive theoretical basis for both practical and research applications. First, no approach to date suffices to capture all the features of the motivational construct. While the socio-psychological approach, for instance, fails to capture the "temporal" feature, the process-oriented model appears to simplify the "dynamic" aspect of motivation in its temporal axis. Second, most approaches tend to emphasize the initial phase of a motivational process (i.e. the reasons for people's choice of a certain course of action), while ignoring or depreciating the importance of sustaining learner's motivation during an L2 learning process (i.e. how and why a learner continues to engage or choose to disengage in learning an L2). The only model that does justice to executive motivational sources - Dörnyei's and Ottos's (1998) process model of L2 motivation - unfortunately seems to display one former shortcoming: insufficient in portraying the "dynamic" feature of motivation (Bower, 2019). Third, all born in the contexts where English is a typical second language, the above theories might be offering a narrow view of L2 motivation, excluding some priorities and experiences of LOTEs learners and thus failing to cover all the nuances of their motivation (Berardi-Wiltshire, Bortolotto \& Morris, 2020). As explained by Ushioda (2017), the futureoriented and goal-based nature of L2 motivation as depicted in the mentioned theories has necessarily associated L2 motivation discourses with "necessity, utility, advantage, power, advancement, mobility, migration and cosmopolitanism" (p. 417), the concepts that may not fully apply to the reasons behind individuals learning minority languages not connected with economic utility or hegemonic status. Furthermore, some concepts no longer deemed much meaningful to learning English as a global language, such as integrativeness (Coetzee-Van Rooy, 2006), has now been found resurface in LOTEs motivation research (Al-Hoorie, 2017). Finally, past and current views on L2 motivation tend to assume, at least implicitly, that L2 learners are rational individuals who are conscious of and able to articulate their drives in L2 learning (Al-Hoorie, 2017). In other words, the importance of unconscious motivators, which has recently gained scholarly attention in mainstream psychology (Ryan \& Legate, 2012), is still largely overlooked, leaving much room in the L2 motivation field to be enriched.

These points imply several recommendations for both practitioners and researchers. For L2 instructors, including those in Vietnam context, even simple psychological techniques such as encouraging in students the positive attitudes towards the targeted language, people, and culture, or emphasizing the instrumental benefits of learning the L2 can be powerful ways to instil the initial drive for students to learn a second language (Dörnyei, 2007). However, since students' motivation is ever-changing and unstable, teachers must invest constant effort in sustaining student's motivation throughout the learning process. This can be done by maximizing student's freedom in pursuing their own learning styles, nurturing self-esteem and autonomy in them (Rahmanpana, 2017), or prioritizing effortrelated feedback over the ability-related type (Dörnyei, 2007). In addition, helping students to understand their current self, and directing them towards a suitable ideal self image would also be an effective way to create on-going motivation in L2 classes (King, Yeung \& Cai, 2019). Last but not least, since motivation is individually different and context sensitive, teachers should be flexible in choosing motivational techniques to apply in classrooms. As emphasized by Dörnyei (2007), while it is necessary for teachers to be aware of the vast repertoire of possible motivational strategies, a motivating teaching practice must be tailored based on the "specific needs that arise" in their "concrete circumstances" (p. 731). The integrative motivational technique, for instance, might work well with learners who demonstrate a genuine interest in the targeted culture, but is highly likely to fail with those whose sole goal of learning the L2 is to earn a promotion at work.

For L2 researchers, it is advisable that the motivation construct should be viewed from different angles to obtain a more comprehensive understanding. Several useful directions for research include, first of all, applying multiple theoretical lenses since no theory or concept alone is sufficient in capturing the nuances of L2 motivation (Bower, 2019). In a review extending over a decade, Boo et al. (2015) have in fact observed a surge of "more than one concept" studies since 2011, which typically 
paired the LLMS with another motivation theory - the trend still prevalent until today in motivation research (e.g. Bower, 2019; BerardiWiltshire et al., 2020). Conceptual pairing, according to these authors, would on the one hand allow for an extended understanding of L2 motivation in a given context; and on the other, create room for juxtaposing different theoretical perspectives, thus enabling possible expansion of the theoretical basis in the area (Boo et al., 2015; King et al., 2019). When comparing empirical studies framed under multiple theoretical lenses, McEown et al. (2014) also concluded that L2 outcome variables are best explained under a framework that combines key concepts from different approaches. Second, the unexplored unconscious motivators in L2 learning are also an area that holds potential for future research. The inclusion of implicit processes such as implicit attitudes, implicit self-concepts, implicit prejudice, may move the field towards an equivalent place with other educational psychology sub-disciplines where unconscious motivation, or "the other side" of the motivation construct, has been duly investigated (Al-Hoorie, 2017).

Methodologically, future researchers are advised to adopt longitudinal designs (Ortega, 2009). Unlike the cross-sectional methods that dominate current L2 motivation research (McEown, 2014), long-term investigations would unfold the revolutionary trajectories of the motivation processes, and thus be able to capture the temporal and long-term feature of L2 motivation (Al-Hoorie, 2017). Finally, the inadequate affordance of LOTEs in the scope of the current L2 motivation theories points to a critical need for inquiries into relatively unexplored motives in relatively unexplored contexts, among which, ones involving the learning of minority, indigenous, or heritage languages should deserve special attention (MacIntyre, Baker, \& Sparling, 2017, p. 501). Findings of this research strand would complement the current L2 motivation theories, expanding their scope to include the complexities involved in the LOTEs contexts as well.

\section{Conclusion}

This literature review has chronologically described and critiqued the major approaches to understanding L2 motivation to date. It has highlighted motivation as a determinant factor in L2 learning, and a construct attracting growing attention in L2 and educational psychology research. The paper also argued that the literature still lacks a comprehensive framework to depict L2 motivation, especially in the context of LOTEs, suggesting the need for both teachers and researchers to be critical and inclusive in their choice of a motivational theory to apply to their practice and research.

Such an observation matches what Dornyei wrote more than two decades ago; that is, "motivation is indeed a multifaceted rather than a uniform factor and no available theory has yet managed to represent it in its total complexity" (1998, p. 131). This review though, by putting all notable L2 motivation theories and models in one place, is hoped to have described different facets of the construct, and equipped researchers and teachers with an integrative repertoire of strategies to explore and nurture students' L2 motivation. Put in MacIntyre and associates' words (2010), the review may have provided "complementary, and perhaps richer, ways of understanding motivation and language learning" (p. 1).

A limitation of this review should be acknowledged. That is, the list of the L2 motivational models and theories reviewed in this paper is not exhaustive. Although the author is confident that the most influential ones have been covered, a new theory might have evolved beyond the author's awareness and thus may have been missed in the paper. Future work with more resources can expand the current review and complete the picture of L2 motivation it has depicted. 


\section{References}

Alexander, P. A., \& Murphy, P. K. (1998). A test of cognitive and motivational dimensions of domain learning. Journal of Educational Psychology, 90, 435-447.

Al-Hoorie, A. H. (2017). Sixty years of language motivation research: Looking back and looking forward. SAGE Open, 7(1), 1-11. https://doi.org/10.1177/2158244017701976

Belmechri, F., \& Hummel, K. (1998). Orientations and motivation in the acquisition of English as a second language among high school students in Quebec city. Language Learning, 48, 219-44.

Berardi-Wiltshire, A., Bortolotto, M. C., \& Morris, H. (2020). Motivation as ethical self-formation in learning te reo Māori as a second language. Journal of Multilingual and Multicultural Development, 1-13. http://doi.org/10.1080/01434632.2020.1804573

Boo, Z., Dörnyei, Z., \& Ryan, S. (2015). L2 motivation research 2005-2014: Understanding a publication surge and a changing landscape. System, 55, 145-157.

Bower, K. (2019) Explaining motivation in language learning: A framework for evaluation and research. The Language Learning Journal, 47(5), 558-574. https://doi.org/10.1080/09571736.2017.1321035

Cave, A., \& Mulloy, M. (2010). How do cognitive and motivational factors influence teachers' degree of program implementation? A qualitative examination of teacher perspectives. National Forum of Educational Administration and Supervision Journal, 27(4), 1-26.

Cheng, H. F., \& Dörnyei, Z. (2007). The use of motivational strategies in language instruction: The case of EFL teaching in Taiwan. Innovation in Language Learning and Teaching, 1(1), 153-174.

Clément, R., Dörnyei, Z., \& Noel, K. A. (1994). Motivation, self-confidence and group cohesion in the foreign language classroom. Language Learning, 44, 417-448.

Coetzee-Van Rooy, S. (2006). Integrativeness: Untenable for world Englishes learners? World Englishes, 25, 437450. https://doi.org/10.1111/j.1467-971X.2006.00479.x

Cook, D. A., \& Artino, A. R. (2016). Motivation to learn: An overview of contemporary theories. Medical education, 50(10), 997-1014.

Crookes, G., \& Schmidt, R. (1991). Motivation: Reopening the research agenda. Language Learning, 41, 469-512.

Darmanto (2020). The roles of a native English speaker teacher (NEST) on the students' motivation in learning English: A case study at SMAN 2 Sumbawa Besar. TESOL International Journal, 15(1), 93-99.

Day, C. (1999). Developing teachers: Challenges of lifelong learning. Falmer Press.

Deci, E. L., \& Ryan, R. M. (1985). Intrinsic motivation and self-determination in human behavior. Plenum.

Ditual, R. C. (2012). The motivation for and attitude towards learning English. The Asian EFL Journal, 63, 4-21.

Dörnyei, Z. (1994). Motivation and motivating in the foreign language classroom. The Modern Language Journal, 78, 273-284.

Dörnyei, Z. (2001a). Motivational strategies in the language classroom. Cambridge University Press.

Dörnyei, Z. (2001b). Teaching and researching motivation. Longman.
Dörnyei, Z. (2002). The motivational basis of language learning tasks. In P. Robinson (Ed.), Individual differences and instructed language learning (pp. 137-158). John Benjamin.

Dörnyei, Z. (2005). The psychology of the language learner: Individual differences in second language acquisition. Erlbaum.

Dörnyei, Z. (2007). Creating a motivating classroom environment. In J. Cummins \& C. Davison (Eds.), International handbook of English language teaching (pp. 719-731). Springer.

Dörnyei, Z. (2009). The L2 motivational self system. In Z. Dörnyei \& E. Ushioda (Eds.), Motivation, language identity and the L2 self (pp. 9-42). Multilingual Matters.

Dörnyei, Z., \& Csizé, K. (2002). Some dynamics of language attitudes and motivation: Results of a longitudinal nationwide survey. Applied Linguistics, 23, 421-462.

Dörnyei, Z., MacIntyre, P. D., \& Henry, A. (Eds.). (2015). Motivational dynamics in language learning. Multilingual Matters.

Dörnyei, Z., \& Otto, I. (1998). Motivation in action: A process model of L2 motivation. Working Papers in Applied Linguistics, 4, 43-69.

Dörnyei, Z., \& Ushioda, E. (2009). Motivation, language identity and the L2 self. Multilingual Matters.

Duff, P. A. (2017). Commentary: Motivation for learning languages other than English in an English-dominant world. The Modern Language Journal, 101(3), 597-607.

Ellis, R. (2008). The study of second language acquisition. Oxford University Press.

Gardner, R. C. (1985). Social psychology and second language learning: The role of attitudes and motivation. Edward Arnold.

Gardner, R. C. (2004). Attitude/Motivation Test Battery: International AMTB research project. The University of Western Ontario. http://publish.uwo.ca/ gardner/docs/englishamtb.pdf

Gardner, R. C. (2010). Motivation and second language acquisition: The socio-educational model. Peter Lang.

Gardner, R. C., \& Lambert, W. E. (1972). Attitudes and motivation in second-language learning. Newbury House Publishers, Inc.

Gardner, R. C., \& MacIntyre, P. D. (1993). A student's contributions to second-language learning. Part II: Affective variables. Language Teaching, 26, 1-11.

Gonzales, R. DLC. (2010). Motivational orientation in foreign language learning: The case study of Filipino Foreign Language Learners. TESOL Journal, 3, 3-28.

Graham, S., \& Weiner, B. (2012). Motivation: Past, present, and future. In K. R. Harris, S. Graham, T. Urdan, C. B. McCormick, G. M. Sinatra \& J. Sweller (Eds.), APA Educational Psychology Handbook: Vol. 1. Theories, constructs, and critical issues (pp. 367397). American Psychological Association. https://doi.org/10.1037/13273-013

Hadfield, J., \& Dörnyei, Z. (2013). Motivating learning. Longman.

Higgins, E. T. (1987). Self-discrepancy: A theory relating self and affect. Psychological Review, 94, 319-340. https://doi.org/10.1037/0033-295X.94.3.319

Hiromori, T. (2009). A process model of L2 learners' motivation: From the perspectives of general tendency and individual differences. System, 37, 313-321. 
Inbar, O., Donitsa-Schmidt, S., \& Shohamy, E. (2001). Students' motivation as a function of language learning: The teaching of Arabic in Israel. In Z. Dörnyei \& R. Schmidt (Eds.), Motivation and second language acquisition (pp. 297-311). National Foreign Language Resource Center.

Kazdin, A. E. (2000). Encyclopedia of psychology. American Psychological Association.

Khudur, S. (2019). Kurdish students' motivation to study in Hungary. BirLE-Journal, 2(2), 6-15.

King, R., Yeung, S. S., \& Cai, Y. (2019). Personal investment theory: A multi-faceted framework to understand second and foreign language motivation. System, 86, 1-10.

Kruidenier, B., \& Clement, R. (1986). The effect of context on the composition and role of orientations in second language acquisition. International Center for Research on Bilingualism.

Lai, Y., \& Aksornjarung, P. (2018). Thai EFL learners' attitudes and motivation towards learning English through content-based instruction. Malaysian Online Journal of Educational Studies, 6(1), 43-65.

Lukmani, Y. (1972). Motivation to learn and language proficiency. Language Learning, 22, 261-273.

MacIntyre, P. (2002). Motivation, anxiety and emotion in second language acquisition. In P. Robinson (Ed.), Individual differences and instructed language learning (pp. 45-68). John Benjamins.

MacIntyre, P. D., Baker, S. C., \& Sparling, H. (2017). Heritage passions, heritage convictions, and the rooted L2 self: Music and Gaelic language learning in Cape Breton, Nova Scotia. The Modern Language Journal, 101(3), 501-516.

MacIntyre, P. D., Noels, K. A., \& Moore, B. (2010). Perspectives on motivation in second language acquisition: Lessons from the Ryoanji Garden. In M. T. Prior, Y. Wantanabe \& S. K. Lee (Eds), Selected Proceedings of the 2008 Second Language Research Forum (pp. 1-9). Cascadilla Press.

Markus, H. R., \& Nurius, P. (1986). Possible selves. American Psychologist, 41, 954-969.

Masgoret, A. M., \& Gardner, R. C. (2003). Attitudes, motivation, and second language learning: A metaanalysis of studies conducted by Gardner and his associates. Language Learning, 52(1), 167-210.

McEown, M. S., Noels, K. A., \& Chaffee, K. E. (2014). At the interface of the socio-educational model, selfdetermination theory and the L2 motivational self system models. In K. Csizér \& M. Magid (Eds.), The impact of self-concept on language learning (pp. 1950). Multilingual Matters.

Ortega, L. (2009). Understanding second language acquisition. Routledge.

Otoshi, J., \& Heffernan, N. (2011). An analysis of a hypothesized model of EFL students' motivation based on self-determination theory. The Asian EFL Journal, 13(3), 66-86.

Papi, M., Bondarenko, A. V. Mansouri, Feng, L., \& Jiang, C. (2018). Rethinking L2 motivation research: The $2 \times 2$ model of self-guides. Studies in Second Language Acquisition, 41(2), 337-361.

Rahmanpanah, H. (2017). Investigating teachers' communicative styles in EFL context: A selfdetermination theory perspective. Journal of Applied Linguistics and Language Research, 4(1), 268-289.

Rau, P. L., Gao, Q., \& Wu, L. M. (2008). Using mobile communication technology in high-school education; motivation, pressure, and learning performance. Computer \& Education, 50(1), 1-22.

Ryan, R. M., \& Deci, E. L. (2000). Self-determination theory and the facilitation of intrinsic motivation, social development, and well-being. American Psychologist, 55, 68-78.

Ryan, R. M., \& Legate, N. (2012). Through a fly's eye: Multiple yet overlapping perspectives on future directions for human motivation research. In R. M. Ryan (Ed.), The Oxford handbook of human motivation (pp. 554-564). Oxford University Press.

Thurman, J. (2013). Choices and its influence on intrinsic motivation and output in task-based language teaching. The Asian EFL Journal, 15(1), 202-245.

Ushioda, E. (2009). A person-in-context relation view of emergent motivation, self and identity. In Z. Dörnyei \& E. Ushioda (Eds.), Motivation, language identity and the L2 self (pp. 215-228). Multilingual Matters.

Ushioda, E., \& Dörnyei, Z. (2012). Motivation. In S. M. Gass \& A. Mackey (Eds.), The Routledge handbook of second language acquisition (pp. 396-409). Routledge.

Weiner, B. (1992). Human motivation: Metaphors, theories, and research (2nd ed.). Sage.

Williams, M., Burden, R., Poulet, G., \& Maun, I. (2004). Learners' perceptions of their successes and failures in foreign language learning. The Language Learning Journal, 30(1), 19-29. http://doi.org/10.1080/09571730485200191 


\title{
TA̛O ĐỘNG LỰC CHO NGƯỜI HỌC NGOAI NGŨ: TỬ CÁC LÝ THUYẾT PHỔ BIẾN TỚI VIỆC ÂP DỤNG TRONG NGHIÊN CỨU VÀ THỰC HÂNH
}

\author{
Trương Thị Mỹ \\ Trường Đại học Hà Nội \\ Km 9, đường Nguyễn Trãi, quận Nam Tù Liêm, Hà Nội, Việt Nam
}

Tóm tắt: Động lực của người học từ lâu đã được khẳng định là một yếu tố quyết định trong quá trình học tập nói chung và việc học ngôn ngữ thứ hai nói riêng. Tương xứng với tầm quan trọng của vấn đề, rất nhiều lý thuyết và mô hình nhằm lý giải động lực học ngôn ngữ thứ hai đã ra đời. Tuy vậy, sự đa dạng về số lượng các đường hướng và mô hình có thể đã gây ra không ít khó khăn cho những người làm chuyên môn muốn lựa chọn một lý thuyết phù hợp nhất cho nghiên cứu hay thực tế giảng dạy của mình. Bài viết nhằm mục đích tháo gỡ khó khăn này thông qua việc tổng hợp và phân tích các đường hướng và mô hình lý giải động lực học ngôn ngữ thứ hai phổ biến từ trước tới nay. Trên cơ sở đó, tác giả đưa ra một số đề xuất mang tính thực tiễn cho giáo viên ngoại ngữ/ngôn ngữ thứ hai và mang ý nghĩa phương pháp luận cho các nhà nghiên cứu muốn tìm hiểu một cách toàn diện hơn về khái niệm động lực học ngoại ngữ hay ngôn ngữ thứ hai.

Tư khóa: động lực học ngôn ngữ thứ hai, tổng quan lý thuyết, dạy học ngôn ngữ thứ hai, lý thuyết về động lực học ngôn ngữ thứ hai 